\title{
GÊNERO NOTÍCIA: MOVIMENTOS DISCURSIVIZADOS NOS LIMITES ENTRE INFORMAÇÃO E OPINIÃO
}

\author{
GÉNERO NOTICIA: LOS MOVIMIENTOS DE DISCURSIVIDAD EN LOS LÍMITES ENTRE LA \\ INFORMACIÓN Y LA OPINIÓN
}

\section{NEWS GENRE: DISCURSIVE MOVEMENTS IN THE LIMITS BETWEEN INFORMATION AND OPINION}

\author{
Adriana Delmira Mendes Polato* \\ Universidade Estadual do Paraná - UNESPAR-PR, Campo Mourão, BR \\ Neil Armstrong Franco de Oliveira** \\ Universidade Estadual de Maringá - UEM, Maringá, BR
}

\begin{abstract}
RESUMO: O trabalho apresenta, a partir da consideração de aspectos extralinguísticos e linguísticos, uma análise de movimentos discursivizados que servem, concomitantemente, à função informativa e, sobretudo, à defesa de uma posição axiológica institucional que se efetiva na notícia. As proposições do Círculo de Bakhtin (1994; 2003; 2006; 2007; 2008), reunidas na proposta da Análise Dialógica de Discurso (BRAIT, 2006), amparam a discussão. A análise de aspectos linguísticos corre ilustrada via categorias da gramática normativa e realça a descrição das formas linguísticas a partir das quais a instituição marca sua posição axiológica, revelando sua opinião. Foi observado um corpus de trinta notícias, cujos excertos servem à exemplificação e das quais duas são analisadas na íntegra.
\end{abstract}

PALAVRAS-CHAVE: Notícia. Parcialidade. Relações dialógicas. Movimentos discursivizados.

RESUMEN: El trabajo presenta, desde la consideración de los aspectos extralingüísticos y lingüísticos, un análisis de movimientos de discursividad que sirven, conjuntamente, a la función informativa y, además, a la defensa de una posición axiológica institucional que se realiza en la noticia. Las proposiciones del Círculo de Bakhtin (1994, 2003, 2006, 2007, 2008) que se reúnen en la propuesta del Análisis Dialógico del Discurso (BRAIT, 2006) son las bases para la discusión. El análisis de los aspectos lingüísticos se ilustra por medio de categorías de la gramática normativa y pone de relieve la descripción de las formas lingüísticas desde las cuales la institución señala su posición axiológica, manifestando su opinión. Se ha observado un corpus de 30 noticias, cuyos fragmentos sirven para ejemplificar y de los cuales dos se analizan por completo.

PALABRAS CLAVE: noticia; parcialidad; relaciones dialógicas; movimientos de discursividad

ABSTRACT: This paper presents, upon the consideration of extra linguistic and linguistic aspects, the analysis of discursive movements applied to the informative function and, above all, to the defense of an institutional axiological position arising from the news. Bakhtin Circle's propositions (1994, 2003, 2006, 2007, 2008) gathered in the proposal of the Dialogic Speech Analysis (BRAIT, 2006) support the discussion. The analysis of linguistic aspects is illustrated by categories of the normative grammar and highlights the description of linguistic forms from which the institution marks its axiological position, disclosing its opinion. We have analyzed a corpus composed by 30 texts, with several extracts being used as examples, and from which two have been analyzed in full.

KEYWORDS: news; partiality; dialogic relations; discursive movements.

\section{INTRODUÇÃO²}

Compreender a constituição e o funcionamento dialógico e discursivo de alguns dos gêneros do discurso jornalístico tem sido empenho de autores da Linguística Aplicada, tais como Acosta-Pereira (2013), Rodrigues (2001), Brait e Pistori (2012), Alves Filho (2006) e outros, que, na via de contribuir com professores e pesquisadores, que se interessam pelo ensino e aprendizagem, envolvendo gêneros desse

\footnotetext{
* Professora de Língua Portuguesa e Prática de Ensino de Língua Portuguesa no Departamento de Letras da UNESPAR - Campus Campo Mourão. Doutoranda em Estudos da Linguagem pela Universidade Estadual de Maringá. E-mail: ampolato@gmail.com.

** Professor Doutor do Departamento de Teorias Linguísticas e Literárias da Universidade Estadual de Maringá - UEM. E-mail: prof.neilfranco@gmail.com.

2 Trabalho vinculado ao Projeto de pesquisa “Escrita e formação de educadores de língua”, processo n 2305/2014, Universidade Estadual de Maringá
} 
campo, evidenciam a necessidade de uma postura dialógica frente a esses objetos semiotizados, cuja presença maciça na vida social demanda a atenção dos estudiosos da linguagem.

É a partir da perspectiva dialógica de trabalho com os gêneros, a qual revisita as obras do Círculo de Bakhtin, a fim de colher substância para observar aspectos linguísticos e extralinguísticos do discurso, internos e externos do gênero na sua orientação na realidade, que tomamos o gênero notícia como objeto de discussão. Empenhamo-nos em desvelar como sua função social não está restrita à informação, mas também à opinião, na medida em que serve à manifestação de uma posição axiológica institucional. Por isso, interessa-nos a análise de aspectos extralinguísticos (relações dialógicas) e linguísticos que ilustram essa natureza parcial.

Para sustentar essa discussão, este texto apresenta, na primeira seção, conceitos do Círculo de Bakhtin e algumas disposições da Linguística Aplicada que amparam a discussão. Na segunda seção, discutimos o enquadramento valorado do discurso do outro na notícia e os movimentos discursivizados de avaliação pelo próprio autor institucional, a partir dos quais a instituição deixa escapar seus posicionamentos. Por fim, na última seção, procedemos à análise de dois exemplares de notícias na íntegra, visando superar a descrição exemplificada por excertos feita nos primeiros tópicos.

A descrição e a análise empreendida demonstram a presença de certas visadas dialógico-valorativas presentes na notícia, as quais são descritas como movimentos discusivizados estilísticocomposicionalmente, saturados de projeções ideológicas (ACOSTA-PEREIRA, 2013). Estas servem, concomitantemente, à função informativa e, sobretudo, à defesa de uma posição axiológica institucional.

\section{METODOLOGIA}

Trata-se de uma pesquisa qualitativo-interpretativista que se insere no campo da Linguística Aplicada, a partir de um percurso transdisciplinar de investigação. Tal perspectiva, de acordo com Signorini (1998), não reduz e não fragmenta o objeto de estudo, de forma que o concebe como múltiplo e complexo, sendo possível deslocar fronteiras disciplinares estabelecidas para sua abordagem mais produtiva.

Delimitamos um corpus de estudo constituído por trinta (30) notícias publicadas em meio eletrônico e dele extraímos excertos para descrever o funcionamento dialógico-valorativo do enquadramento do discurso do outrem. Evidenciamos as formas linguísticas de concretização desses movimentos discursivizados, as quais servem à avaliação (aproximação ou distanciamento do discurso do outro) e/ou à validação do discurso novo.

Explicitamos, também, a presença de movimentos discursivizados de avaliação pelo autor institucional, não relacionados ao discurso citado, os quais podem ser observados a partir de especificações e retomadas textuais de assunto, quando a instituição jornalística deixa entrever seus posicionamentos, o que acaba por confirmar a natureza não parcial do discurso citado.

Por fim, extraímos dois exemplares do corpus de notícias para serem analisados na íntegra. Tal proposta visa superar a descrição exemplificada por excertos, evidenciando a importância dos aspectos extralinguísticos (relações dialógicas) para compreensão dos aspectos linguísticos, os quais podem ser mais bem compreendidos a partir de que tomamos as formas típicas de enunciados concretos para análise integral. Essas duas notícias são analisadas em uma relação dialógica que mantêm com um editorial publicado pelo jornal $O$ Globo, anteriormente. Dessa forma, podemos destacar a parcialidade de ambas, na medida em que uma delas refuta e a outra reforça o conteúdo do texto antecedente.

As terminologias utilizadas na descrição e na análise se dão via Nomenclatura Gramatical Brasileira (NGB). Do ponto de vista de nossa ancoragem teórica, valemo-nos das propostas da Análise Dialógica do Discurso (ADD), cujo "trabalho metodológico, analítico e interpretativo ocorre por meio da herança advinda da linguística” (DE PAULA, 2013, p. 252), buscando

[...] esmiuçar campos semânticos, descrever e analisar micro e macro-organizações sintáticas, reconhecer, recuperar e interpretar marcas e articulações enunciativas que caracterizam o(s) discurso(s) e indicam sua heterogeneidade constitutiva, assim como a dos sujeitos aí instalados. E mais ainda: ultrapassando a necessária análise dessa 'materialidade linguística', reconhecer o gênero a que pertencem os textos e os gêneros que nele se articulam, descobrir a tradição das 
atividades em que esses discursos se inserem e, a partir desse diálogo com o objeto de análise, chegar ao inusitado de sua forma de ser discursivamente, à sua maneira de participar ativamente de esferas de produção, circulação e recepção, encontrando sua identidade nas relações dialógicas estabelecidas com outros discursos, com outros sujeitos (BRAIT, 2006, p. 13).

A ADD assume interesse para observar as regularidades enunciativo-discursivas presentes no funcionamento do gênero do discurso, a fim de "entender a relativa estabilização linguístico-enunciativa desse gênero" (RODRIGUES; ACOSTA PEREIRA, 2010, p. 152). No entanto, esse interesse não está a serviço de compreender as formas fixas da língua, mas as "regularidades e similaridades das relações sociais numa esfera de comunicação específica” (ROJO, 2005, p. 199).

\section{DAS DISCUSSÕES BAKHTINIANAS E DA LINGUÍSTICA APLICADA À ANÁLISE}

Em várias obras do Círculo de Bakhtin, evidencia-se a natureza da linguagem concebida como fenômeno dialógico e discursivo passível de ser observado apenas a partir das enunciações reais. Da mesma forma, dáse atenção aos aspectos da concretude linguística, de forma a não se desprezar as contribuições da Linguística. Numa acepção bakhtiniana, portanto, estudar a língua não pode ser investigar "tudo aquilo que, tendo se formado e determinado de alguma maneira no psiquismo do indivíduo, exterioriza-se objetivamente para outrem com a ajuda de algum código de signos exteriores" (BAKHTIN [VOLOSHÍNOV], 2006, p. 113). Tampouco é considerar que todos os fatos da língua situam-se no sistema linguístico, ou seja, no sistema das formas fonéticas, gramaticais e lexicais da língua separadas de seu conteúdo ideológico.

Brait (2006) recupera a discussão de Bakhtin em Problemas da poética de Dostoievski, quando o autor se dedica a realçar o caráter dialógico dos enunciados. Para Bakhtin (2008) o discurso é o objeto multifacetado do qual se devem observar as dimensões extralinguísticas (externas) e linguísticas (internas). Por isso, propõe revestir o objeto a ser estudado - o discurso - com uma dimensão extralinguística. Dessa forma, distanciase em parte da linguística objetiva para destacar a importância das relações dialógicas, visto que considera o discurso como um cruzamento de discursos.

Em Marxismo e filosofia da linguagem, Bakhtin [Voloshínov] (2006) apresenta uma nova ordem metodológica para o estudo da língua, em que os gêneros aparecem em segundo lugar. O primeiro é reservado às enunciações reais e o último às concretizações linguísticas, permitindo-nos depreender a necessidade de olhar os aspectos internos e externos do gênero em sua orientação na realidade.

Conforme expõem Brait e Pistori (2012), Medvedev e Bakhtin (2008) esmiúçam melhor essa questão em $O$ método formal nos estudos literários: uma introdução crítica a uma poética sociológica, explicitando a improdutividade do estudo do gênero somente a partir dos elementos formais da língua. Para eles, é necessário observar a dupla orientação do gênero na realidade a partir de uma orientação externa, que diz respeito ao tempo, ao espaço, ao campo da atividade de onde o enunciado emerge, orientado a interlocutores e, por outro lado, a partir de uma orientação interna, "relacionada a formas, estruturas e conteúdo temático do enunciado em sua totalidade, fator que lhe permite ocupar um lugar na vida cotidiana, unindo-se ou aproximando-se de uma esfera ideológica" (BRAIT; PISTORI, 2012, p.382, grifo das autoras).

Dessa forma é que Bakhtin (2003, p. 261), considerando a relação entre campo e enunciado, afirma que "o emprego da língua efetua-se em forma de enunciados (orais ou escritos) concretos e únicos, proferidos pelos integrantes desse ou daquele campo da atividade humana". Para o autor, esses enunciados refletem as condições específicas e as finalidades do campo, não só por seu conteúdo (temático) e pelo estilo da linguagem, mas, sobretudo, por sua construção composicional.

Não diferentemente, Bakhtin [Voloshínov] (2006) afirma:

Cada campo de criatividade ideológica tem seu próprio modo de orientação para a realidade e refrata a realidade à sua própria maneira. Cada campo dispõe de sua própria função no conjunto da vida social. É seu caráter semiótico que coloca todos os fenômenos ideológicos sob a mesma definição geral (BAKHTIN [VOLOSHÍNOV] 2006, p. 34, grifos do autor). 
Já a considerar o que é externo e interno ao gênero, por ressaltar a importância do campo, Bakhtin (2003) defende a indissolúvel ligação entre os três elementos que o compõem (conteúdo temático, estilo verbal e construção composicional). Essa afirmação encontra eco em outras reflexões do Círculo e nos delega a obrigação de considerá-las.

Em Marxismo e filosofia da linguagem, no capítulo "Tema e significação na língua”, Bakhtin [Voloshínov] (2006) explica que a observação da palavra nas enunciações concretas está orientada a um estágio superior o tema. Diferentemente, se há tentativa de sacar a significação da palavra do sistema linguístico isolado, a orientação é inferior - significação. Isso porque,

para o locutor, a forma linguística não tem importância enquanto sinal estável e sempre igual a si mesmo, mas somente enquanto signo sempre variável e flexível. Este é o ponto de vista do locutor. Mas o locutor também deve levar em consideração o ponto de vista do receptor (BAKHTIN [VOLOSHÍNOV], 2006, p.92).

Não se pode observar a valoração ideológica da palavra, entendê-la como signo ideológico, fora das enunciações concretas, à parte de sua orientação superior - o tema, porque "não é uma palavra isolada que está orientada para o tema, mas o enunciado inteiro como atuação discursiva” (BRAIT; PISTORI, 2012, p. 384). Assim, "O tema e a forma do signo ideológico estão indissoluvelmente ligados, e não podem, por certo, diferenciar-se a não ser abstratamente. Tanto é verdade que, em última análise, são as mesmas forças e as mesmas condições que dão vida a ambos" (BAKHTIN [VOLOSHÍNOV], 2006, p. 45).

Nesse sentido, cada signo, quando tomado em dado momento histórico-social, serve aos sistemas semióticos que exprimem a ideologia e são, concomitantemente, modelados por ela. A palavra é um signo ideológico porque é capaz de registrar as variações das relações sociais, por menores que estas sejam, daí a natureza interacional da linguagem.

Bakhtin(2003) afirma que a tarefa do sujeito do discurso é dar conta de um tema. Para isso, não tomará a palavra do sistema linguístico abstrato para seu dizer, mas de já-ditos em outros enunciados. Assumindo o papel de autor, ao elaborar um enunciado novo, tratará de dar acabamento a ele. No entanto, a escolha dessa forma típica de enunciado é precedida pela necessidade de "dar conta do tema" e também do intuito/vontade discursiva do sujeito do discurso. Já numa forma típica de enunciado, sempre dirigido a outros interlocutores, o tema, conteúdo do qual se ocupa o sujeito do dizer, agora conteúdo temático, constituirá o enunciado juntamente com o estilo verbal e a construção composicional, de forma indissolúvel.

Quanto ao estilo, Bakhtin (2003, p. 283) defende, acima de tudo, o estilo genérico, mas não ignora a existência do estilo individual. Para o autor, nem todos os gêneros são igualmente propícios ao reflexo da individualidade do sujeito falante. $\mathrm{O}$ estilo individual não está separado da existência do gênero.

Compreender isso implica distinguir entre o que postula como estilo do gênero e o que postula como estilo individual de linguagem. $\mathrm{O}$ estilo do gênero diz respeito às escolhas lexicais, gramaticais, fraseológicas próprias de uma forma típica de enunciado, cujas significações consubstanciadas pela situação concreta de uso e pelo gênero têm sentido valorado. Já o estilo individual de linguagem, que não é uma expressão individual pura, pois “'individualidade’ criadora constitui a expressão do núcleo central sólido e durável da orientação social do indivíduo" (BAKHTIN [VOLOSHÍNOV], 2006, p. 123), pode emergir, a depender da natureza do enunciado, permitindo-se apresentar certas marcas de uma autoria, embora esta também esteja para as formas típicas de enunciado.

Quanto à construção composicional, Brait e Pistori (2012) retomam de Bakhtin a distinção feita entre forma composicional e forma arquitetônica em O problema do conteúdo, do material e da forma na criação literária:

Bakhtin sugere que é preciso enfrentar a unidade do texto não como dada exclusivamente por sua forma externa, aparentemente autônoma, mas por seu plano, ou seja, por suas condições concretas de vida, suas interdependências, suas relações, suas posições dialógicas e valorativas (BRAIT; PISTORI, 2012, p. 378).

Compreender esses dois aspectos é importante, sobretudo para a observação das relações dialógicas. A construção composicional diria respeito ao caráter mais ou menos estável, utilitário, teleológico do gênero, nos dizeres de Rojo (2005). Já a forma arquitetônica é mais ampla. Relaciona-se ao "aspecto que tem a ver, 
em termos do conjunto da proposta do pensamento bakhtiniano, com a relação eu para o outro - o outro para mim, presente nos textos, nos discursos, nos gêneros" (BRAIT; PISTORI, 2012, p. 378, grifo das autoras). Uma notícia serve a intuitos discursivos específicos e, portanto, sempre está relacionada a outros textos do mesmo jornal e de outros jornais. Sua forma composicional está para as partes relativamente estabilizadas que constituem o gênero internamente e que contribuem para que a notícia cumpra com sua função social de informar (título, subtítulo opcional, lide e corpo). A forma arquitetônica é mais ampla e diz respeito às inter-relações que o texto mantém com os outros textos. Tanto a partir de que se considera a arquitetura, quanto a partir de que se considera a forma composicional, é possível perceber, no estilo do gênero, movimentos discursivizados que respondem a todas essas relações (extralinguísticas e linguísticas).

Outro aspecto interessante à compreensão do enunciado (nesse caso, da notícia) diz respeito a sua autoria. Para Bakhtin (2003), todo o acabamento estilístico e composicional é dado pelo autor. Se há enunciado, há autoria. Bakhtin rebate a existência de uma autoria calcada na individualidade (concepção da estilística clássica) para compreender, conforme nos mostra Faraco (2007), a existência de um autor-criador, que se constitui como uma posição axiológica. Essa posição é a do ser social ou profissional, por exemplo, que fala de determinado lugar da história e de determinado campo da atividade humana. $\mathrm{O}$ autor-criador lê o mundo, sofre coerções e faz escolhas linguísticas, consubstanciadas pelo gênero que serve a sua vontade discursiva na interação com seus interlocutores. Por isso, Bakhtin (2003) entende as escolhas gramaticais feitas pelo autor como já um ato de estilo.

O autor de notícias, conforme Alves Filho (2006), não é um autor individual, mas um autor institucional, ou seja, dá acabamento ao texto a partir de uma posição axiológica demandada pela empresa para qual trabalha. Esse autor não cuida de dar acabamento ao enunciado sem um fim social. Os enunciados são sempre respostas a outros enunciados (de concordância ou discordância) e sempre dirigidos a interlocutores. Assim, ao mesmo tempo em que suscitam, são suscitados, também recuperados e capazes de recuperar outros, porque o dialogismo é um aspecto fundante da língua/linguagem.

\section{O DISCURSO CITADO E A PARCIALIDADE NA NOTÍCIA}

O campo jornalístico, por excelência, enquadra, a partir das diferentes formas de enunciados (seus gêneros), o discurso que vem de outros campos e, até mesmo, o discurso do mesmo campo, como resposta de concordância ou de discordância aos conteúdos veiculados por parceiros ou concorrentes.

Por ser muito fértil à reenunciação, esse campo faz imprimir essa característica em seus gêneros. Conforme Acosta-Pereira (2013), na notícia, o enquadramento de discursos pode ocorrer de duas maneiras, conforme se apresentará na análise do corpus: a) quando o discurso do outro serve ao discurso do autor institucional a partir de que este mantém uma relação de distanciamento ou de engajamento ao discurso de outrem; b) quando o discurso de outrem valida uma afirmação disposta pelo autor institucional.

Para Bakhtin [Voloshínov] (2006, p.149), as formas usadas na citação do discurso refletem "tendências básicas e constantes da recepção ativa do discurso de outrem, e é essa recepção, afinal, que é fundamental também para o diálogo". Dessa forma, podemos entender que as maneiras e os intuitos de se responder aos outros discursos e, também, as formas de enunciado utilizadas para esse cumprimento é que determinam os modos e as finalidades do enquadramento do discurso do outro.

Conforme explica Acosta-Pereira (2013), quando discursos de outrem são dialogicamente enquadrados no discurso de outro autor, submetem-se aos processos de reenunciação e revaloração, determinados pelas diferentes situações de interação, visto que todo enunciado é um evento novo. Em Bakhtin [Voloshínov] (2006, p.150), encontramos direção ao entendimento dessa questão: "o discurso citado é o discurso no discurso, a enunciação na enunciação, mas é, ao mesmo tempo, um discurso sobre o discurso, uma enunciação sobre a enunciação".

Linguisticamente, há diferentes modos para esse enquadramento. Dessa forma, há, por parte de Bakhtin/Voloshínov (2006, p. 47), a preocupação em destacar que "o discurso de outrem constitui mais do que o tema do discurso; ele pode entrar no discurso e na sua construção sintática, por assim dizer, 'em pessoa', como uma unidade integral da construção". 
Para entender como se dá esse enquadramento na notícia, é necessário, anteriormente, compreender a orientação interna desse gênero, a que função social serve e a quê, nele serve, o discurso de outrem. Para Rabaça e Barbosa (1998), no Dicionário de Comunicação, a notícia é o "relato de fatos ou acontecimentos atuais, de interesse e importância para a comunidade e capaz de ser compreendido pelo público".

O gênero se apresenta sócio-historicamente com a função de relatar, com precisão, pressuposta imparcialidade e compromisso de verdade, os acontecimentos do cotidiano de maior relevância e de interesse público. No entanto, na aparente objetividade e imparcialidade, que se camufla no veio da precisão do relato, a justaposição de fatos, o amálgama de discursos de outrem e outras manobras linguísticas ajudam a compor, muitas vezes, quadros tendenciosos. A notícia, então, deixa de ter somente uma função informativa para servir à opinião, ou a uma posição institucional.

Nesse sentido, a presença do discurso de outrem é evidente e necessária ao cumprimento da aparente função apartidária do jornal. Grandemente, é a partir desses discursos e de suas formas de enquadramento que a empresa jornalística acaba por apresentar sua posição. Nesse caso, o discurso de outrem enquadrado no discurso novo, que aparentemente se constitui no plano estilístico-composicional como a serviço da objetividade, da precisão, da verdade e da imparcialidade, funciona, também, como argumento.

Para cumprir sua função informativa, estilístico-composicionalmente, a notícia apresentará movimentos discursivizados para responder a informações fundamentais (lide) como: Quem? O quê? Onde? Quando? Além disso, deve apresentar o relato pormenorizado do que aconteceu, devendo responder às perguntas: Como? Por quê? É com a finalidade aparente de ilustrar esse "como" e esse "por quê", que, geralmente, são enquadrados os discursos de outrem. Conforme afirma Acosta-Pereira (2013), esses movimentos dialógicos discursivizados são valorados e saturados por orientações ideológicas. Por isso, a instituição, a partir de intuito específico, avalia o discurso de outrem ou o utiliza para validar informações que dispõe. Esses movimentos são discursivizados a partir de visadas dialógico-valorativas de avaliação ou de validação.

A primeira diz respeito ao enquadramento avaliado do discurso do outro, ou por orientações construídas por determinados recursos da língua funcionando como índices avaliativos. A segunda diz respeito a quando o discurso de outrem funciona como discurso de autoridade, validando o fato noticiado. Recortamos especial interesse por reapresentar esses movimentos e por descrever algumas de suas possíveis formas linguísticas de concretização.

\subsection{OS MOVIMENTOS DISCURSIVIZADOS DE ENQUADRAMENTO DO DISCURSO DE OUTREM NA NOTÍCIA}

Ao observarmos as formas de enquadramento do discurso de outrem na notícia, verificamos que: a) ele pode ser avaliado negativamente e refutado pelo autor institucional, ou avaliado positivamente para ser tomado como discurso próprio, numa relação de adesão; b) ele pode validar informações ou opiniões dispostas pelo autor institucional.

As formas de enquadramento explícito geralmente ocorrem por meio do discurso direto, marcado com aspeamento, e discurso indireto, introduzido por orações subordinadas substantivas objetivas diretas, ou a partir do "discurso segundo", numa relação que se pode depreender conformativa, questão já apontada por Grillo (2004; 2005).

\subsubsection{Formas concretas de avaliação do discurso do outro}

Quanto às formas de avaliação do discurso de outrem pelo autor institucional, linguisticamente, pudemos distinguir no corpus de análise:

1) Quando internamente ao seu conteúdo, se marcam termos do discurso citado com aspas.

Excerto 01: 
(01) E a outra informava que a diretoria executiva da petroleira brasileira havia aberto uma auditoria para apurar os responsáveis pela "falha no procedimento" e investigar eventuais prejuízos na compra da refinaria (MELO, 2014).

No excerto, o discurso de outrem já havia sido anteriormente introduzido pela oração subordinada substantiva objetiva direta. Embora as aspas sirvam para demarcar/reforçar o discurso do outro, acabam também por questionar o valor dos termos marcados.

2) Quando externamente a seu conteúdo, o discurso citado é avaliado por meio de formas verbais delocutivas:

Excerto 02:

(02) "Qualquer decisão sobre o futuro da Ucrânia deve incluir seu governo legítimo", advertiu o presidente norte-americano em um pronunciamento diante dos meios que não estava previsto, demonstrando, de novo, o apoio de Washington ao Executivo interino ucraniano (SAIZ, 2014).

A forma verbal delocutiva "advertiu" avalia a forma e o tom do pronunciamento do presidente Obama. A utilidade e o intuito dessa avaliação do modo de o outro enunciar poderão ser entendidos com mais precisão a partir da leitura integral da notícia, para que seja observada a posição que se firma.

No plano linguístico, segundo Grillo (2004, p. 117), além de fazerem a interpretação do que é dito, os verbos de elocução podem desempenhar pelo menos quatro funções textuais: a) marcam a presença de um discurso citado no texto; b) resumem o sentido geral do discurso citado; c) condicionam a recepção do discurso citado pelo receptor; e d) organizam o discurso relatado em função da estrutura argumentativa do texto no qual se inserem.

Segundo Gavazzi e Rodrigues (2003), o uso dos verbos declarativos acaba acentuando o aspecto subjetivo por parte de quem enuncia. As autoras trabalham com a hipótese de que a escolha de um desses verbos representa muito mais do que a intenção de informar. Trata-se da tentativa de reproduzir certa ideologia subjacente ao discurso do outro, que se quer qualificar ou desqualificar, dependendo dos interesses de quem enuncia ou para quem enuncia. Assim, conforme as autoras, esses verbos possuem potencial avaliativo, inscrevendo-se com diferentes valores na trama discursiva, como o de aparente neutralidade do "dizer", "afirmar”, "declarar” etc., de valoração positiva, como “explicar”, “aconselhar”, "ponderar” etc., de valoração negativa, no caso, por exemplo, de “acreditar”, “jurar”, “garantir”, “desconversar”, etc. Vemos, portanto, que, na busca pelo efeito de transparência, os verbos de elocução, na verdade, tornam-se recursos reveladores "da interpretação que o jornal faz dos discursos dos atores sociais” (GRILLO, 2004, p. 118).

No excerto em análise, a forma verbal delocutiva "advertiu” confere o tom de ameaça do discurso do presidente Obama aos que se opõem a apoiar o governo interino ucraniano.

3) Quando o autor institucional avalia o discurso do outro a partir de adjuntos adverbiais de modo: Excerto 03:

(03) O Clube Militar reagiu com firmeza (BOCCHINI, 2014).

Por meio do adjunto adverbial de modo, o autor institucional avalia o discurso do Clube Militar.

4) Quando, a partir de manobras linguísticas, o autor institucional estabelece uma relação de distanciamento do discurso de outrem.

\section{Excerto 04:}

(04) As manifestações, segundo ela, seriam "parte indissociável do processo de construção da democracia e de mudança social", em que os "novos cidadãos brasileiros se conscientizam e exigem seus direitos" (WELLE, 2014). 
No excerto em análise, o autor institucional introduz a voz da presidente Dilma a partir do discurso segundo. A expressão "segundo ela" aparece intercalada por vírgulas entre o objeto do discurso (sujeito) "as manifestações" e o que se fala sobre ele. O autor opta pela forma verbal "seriam" no futuro do pretérito, gerando efeito de hipótese e não de certeza. Assim, deixa claro que, segundo a hipótese de Dilma, as manifestações são "parte indissociável do processo de construção da democracia e de mudança social”, em que os "novos cidadãos brasileiros se conscientizam e exigem seus direitos". A partir desses recursos, o autor avalia e direciona a interpretação do leitor para observar que não quer compartilhar especificamente dessas afirmativas feitas pela presidente. Ao se distanciar do discurso do outro, o autor institucional o faz porque o avalia negativamente.

\subsubsection{O DISCURSO DE OUTREM VALIDANDO CONTEÚDOS DISPOSTOS PELO AUTOR INSTITUCIONAL}

Conforme já afirmamos, esse movimento discursivo ocorre quando o discurso de outrem reafirma os fatos relatados, "gerando efeitos de credibilidade e veracidade" (ACOSTA-PEREIRA, 2013).

Excertos 05 e 06:

(05) "O deficit [em 2013] foi causado fundamentalmente pelo menor superavit comercial no ano. Para 2014, deve ocorrer uma redução do deficit", disse Fernando Rocha, chefe-adjunto do Departamento Econômico do BC (FERNANDES, 2014).

(06) Segundo ele, o BC estima um saldo negativo de US\$ 78 bilhões, sendo que boa parte será coberta com o ingresso de US\$ 63 bilhões em investimentos estrangeiros (FERNANDES, 2014).

O título da notícia anuncia que o Brasil tem rombo recorde nas contas externas e, para validar tal afirmação, o autor institucional introduz o discurso de Fernando Rocha, chefe-adjunto do Departamento Econômico do Banco Central, em tese, uma autoridade, conforme se vê em 05. O mesmo ocorre no excerto 06, quando a voz de Fernando Rocha é introduzida a partir do discurso segundo.

\section{OS MOVIMENTOS DE AVALIAÇÃO DISCURSIVIZADOS NO RELATO E O REVELAR DA POSIÇÃO DA INSTITUIÇÃO}

À parte do discurso de outrem, apresentam-se na notícia movimentos discursivizados dos quais o autor institucional faz uso para expressar avaliações. Nesses, incluem-se os movimentos de especificação e os de retomada textual de assunto, fortemente apoiados nos valores sociais e ideológicos do signo.

Pelo fato de a notícia ser um gênero cuja função mais evidente é a informacional, não há, explicitamente em abundância, o uso de elementos linguísticos que servem à avaliação (adjetivos e outros). No entanto, o autor institucional realiza essas avaliações quando, por exemplo: a) marca com aspas termos do próprio discurso; b) faz uso de adjuntos adverbiais de modo; c) realiza explicações por meio de orações subordinadas adjetivas explicativas; d) introduz avaliações inseridas em apostos; e) especifica o objeto por meio de orações subordinadas adjetivas restritivas ou adjuntos adnominais. Observemos um título de notícias que serve a ilustrar $a$ e $b$ :

\section{Excerto 07:}

(07) Garota é brutalmente assassinada e "colegas" preferem silêncio sobre possível autor (JUBANSKI; HERNIQUE, 2014).

No título, aparece o advérbio de modo "brutalmente" avaliando e qualificando a forma do crime. A presença do advérbio destaca a denúncia que o jornal faz logo em seguida, quando marca o termo "colegas" com aspas. Uma avaliação é lançada a partir do valor social atribuído a "colegas". Posteriormente, o autor institucional escolhe a forma verbal "preferem", cujo sentido remete a uma opção realizada e depois a completa com "silêncio sobre possível autor". "Colegas traidores" talvez pudesse expressar, em alguma medida, o efeito de sentido dado pelo uso das aspas no termo "colegas". O adjetivo não está lá para qualificar 
os "colegas", mas as aspas convidam o leitor a partilhar do valor social e ideológico atribuído ao signo, que aspeado ganha outro sentido. Por isso, apesar de a notícia não apresentar adjetivos, a avaliação ocorre por meio de outros recursos. Isso ocorre a partir de uma relação de alteridade, cuja compreensão exige observar como os "usos da linguagem apresentam-se engendrados por particularidades, singularidades e recortes de sentidos afetados, impregnados ou alterados pelas diferentes relações sociais que as constituem" (ACOSTAPEREIRA, 2013, paginação irregular).

Outra forma de qualificar objetos sem o uso de adjetivos é por meio de orações subordinadas adjetivas explicativas ou outros recursos explicativos como os apostos, conforme sugerimos em $c$ e $d$. Esses recursos estão a serviço do autor institucional para que possa dar precisão ao relato e, ao mesmo tempo, expressar avaliações sutis, sob a fórmula de bem prestar o serviço informacional de qualidade a partir de que detalha os fatos. Observemos o exemplo:

Excertos 08 e 09:

(08) Na nova proposta, o governo quer tipificar a exigência como crime, o que fará aumentar a penalidade para três meses a um ano de detenção e aplicação de multa (PIMENTEL, 2012).

(09) O projeto de lei, que muda o código penal, entrará em vigor se aprovado pelo senado (PIMENTEL, 2012).

No excerto 08, percebemos que a oração explicativa anuncia o que acontecerá se o governo conseguir tipificar a exigência como crime. Ao mesmo tempo em que informa, o autor institucional "interpreta/avalia" o teor da ação. No excerto 09, ao explicar que o projeto muda o código penal, o autor institucional destaca a importância do alcance da lei. É como se dissesse "o projeto é de tal importância que modifica até o código penal". Aqui também ocorre, simultaneamente, o ato de informar e o ato de avaliar o conteúdo do projeto.

Sobre especificações por orações subordinadas adjetivas restritivas e adjuntos adnominais, é necessário destacar que a notícia favorece a presença de movimentos discursivizados que se valem dessas recorrências, as quais estamos chamando de visada dialógico-valorativa de especificação ${ }^{3}$. Quanto maior a presença desses movimentos, mais a notícia se inclina à parcialidade. As notícias sensacionalistas são um exemplo muito explícito dessa afirmação. Ao detalhar os objetos do discurso, o jornal sensacionalista o faz porque o detalhe serve à avaliação que lança sobre o objeto, entendendo que o leitor partilha dessa proposta para compreender a gravidade, apreender as formas de ação, por exemplo:

Excerto 10:

(10) Março de 2012: horas antes de um Corinthians e Palmeiras, ontem, em São Paulo, o estudante palmeirense André Alves Lezo levou um tiro após confronto com corintianos (CONFLITO..., 2012).

A partir do excerto, percebemos se concretizar o intuito/vontade discursiva do jornal de denunciar a situação de violência nos estádios de futebol. O adjunto adnominal "estudante palmeirense", ao mesmo tempo em que serve à precisão informacional do relato, serve à denúncia, visto que, de certo modo, qualifica a vítima como não sendo um qualquer, mas um "estudante", o que favorece a interpretação do fato como uma tragédia. Para entender o movimento de especificação não basta identificá-lo, mas é necessário compreender o porquê de seu uso, observando a posição que se firma no restante do texto.

Uma notícia cujo título é "Criança de 3 anos é violentada no Jardim Cruz", especifica, a partir do adjunto adnominal "de 3 anos", que tipo de criança é vítima de violência. Assim, o leitor poderá partilhar da compreensão desse dado.

É importante ressaltar que as explicações e as especificações se engendram para servir à precisão do relato. São diferentes, mas ao mesmo tempo uma quase sempre está relacionada à outra, sendo difícil separar esses domínios dialógico-valorativos, como no caso de olhar para um aposto, por exemplo:

Excertos 11 e 12:

s A visada dialógico-valorativa de especificação está sendo apresentada por Polato e Franco de Oliveira neste trabalho, em complemento às descritas
por Acosta- Pereira (2013). 
(11) Há pouco mais de um mês, o secretário de Recursos Humanos do Ministério do Planejamento, a) Duvanier Paiva Ferreira, b) 56 anos, c) morreu devido a um infarto, depois de ter procurado atendimento em dois hospitais privados de Brasília. Para atendê-lo, as instituições teriam exigido cheque caução. O caso está sendo investigado pela Polícia Civil do Distrito Federal (PIMENTEL, 2012).

(12) Brasília - O governo federal enviou ao Congresso Nacional projeto de lei que criminaliza a exigência de cheque caução, nota promissória ou até preenchimento de formulário para atendimento de emergência em hospitais privados (PIMENTEL, 2012).

No excerto 11, em $a$ e $b$, os apostos explicam quem é o Secretário de Recursos Humanos e, ao mesmo tempo, explicam/especificam sua idade. $\mathrm{O}$ autor institucional explica o motivo da morte para posteriormente estabelecer outras relações com esse fato. Se a idade do secretário não fosse importante à ideia de "muito novo para morrer", talvez a explicação/especificação não tivesse ocorrido para dar o tom de denúncia. No excerto 12, percebemos a oração subordinada adjetiva restritiva especificando que projeto de lei está em discussão no Congresso.

Além dos movimentos discusivizados já explorados, podemos observar, conforme Acosta Pereira (2013), o movimento de retomada textual do assunto também como uma visada dialógico-valorativa. Koch (2005, p.34) defende a anáfora, por exemplo, como "algum tipo de informação alocada na memória discursiva". As retomadas textuais de assunto devem permitir que o interlocutor possa estabelecer a ligação com o elemento referenciado. A empresa jornalística lança determinada apreciação quando referencia ou substitui termos na notícia, mas isso não ocorre de maneira explícita, de modo que é necessário observar também as relações extralinguísticas e o que se apresenta no restante do texto para se compreender essas posições axiológicas. É o jornal (eu) que se dirige ao seu interlocutor (outro), afinando um diálogo altero. Como nesse tópico estamos analisando apenas excertos, procederemos, na análise, a uma breve contextualização do conteúdo geral do enunciado do qual extraímos os excertos, para a compreensão da questão.

\section{Excertos 13 e 14:}

(13) "Democracia gera desejo de mais democracia; inclusão social provoca expectativa de mais inclusão social; qualidade de vida desperta anseio de mais qualidade de vida" e o importante é "transformar a energia das ruas em realizações para todos", enfatizou a política petista (WELLE, 2014).

(14) Ao fim de sua apresentação no fórum, a chefe de Estado brasileira aproveitou para responder a mais um ponto de crítica, assegurando que o país está perfeitamente preparado para a "Copa das Copas"( WELLE, 2014).

Para retomar "Dilma”, na matéria em questão, o autor institucional utiliza-se de referências, como "ela", "a presidente", das quais chamamos atenção para as duas que aparecem nos excertos em análise. Para entender que há uma valoração nesse movimento de retomada, é necessário contextualizar: enquanto grande parte da imprensa se dedica a avaliar negativamente o discurso de Dilma na cidade de Davos, no Fórum Econômico Mundial, no ano de 2014, a notícia publicada por Carta Capital, em meio eletrônico, apresenta o relato dos aspectos positivos do discurso, promovendo a possível interpretação de que os interlocutores inscritos nesse diálogo são de esquerda, ou são apoiadores das políticas do governo petista. Por isso, o termo "a política petista" para retomar "Dilma" positivamente.

Da mesma forma o termo "a chefe de Estado brasileira" situa o discurso de Dilma como daquela que fala em nome de uma nação, de um Estado e que tem poder conferido para isso. Mais uma vez, a empresa afina o diálogo com seus interlocutores a partir da escolha de termo valorado positivamente pela comunidade dos que pactuam com o discurso dito de esquerda.

Os termos de retomada, então, estão crivados de valorações pela constituição social ideológica dos signos em dado momento da história, ou seja, em grande medida pelo que o signo a partir do qual se opera essa retomada representa para uma comunidade de interlocutores. Se a notícia em questão, em todo seu conteúdo, parecesse avaliar negativamente o discurso de Dilma em Davos e fosse dirigida a interlocutores 
contrários a seu governo, o termo "a política petista" certamente ganharia valoração negativa. Assim, concluímos que as visadas dialógico-valorativas de retomada do assunto na notícia são orientadas a partir do próprio discurso e, em grande medida, para quem são interlocutores aos quais a instituição se dirige.

\section{ANÁliSE DE DUAS NOTÍCIAS: ASPECTOS EXTRALINGUÍSTICOS E LINGUÍSTICOS PARA OBSERVAÇÃO DA PARCIALIDADE}

No ano de 2013, o país foi tomado por uma onda de protestos populares reivindicando, sobretudo, melhorias nos serviços públicos e o fim da corrupção. $\mathrm{O}$ aumento do preço das passagens para o transporte público nas grandes metrópoles foi a motivação inicial. O movimento tomou dimensão nacional e pouco a pouco despontou em diversas capitais e também em pequenas cidades país afora. Nesse contexto, as diversas mídias passaram a noticiar, interpretar e dispor opiniões sobre esse movimento político-social. Esse foi um momento de reação e contrarreação, de palavra e contrapalavra aos conteúdos veiculados na mídia e que, por vezes, desfechavam em aspectos positivos e negativos dos protestos num ano de pré-eleições presidenciais.

Em algum momento desse movimento, grupos de manifestantes começaram a bradar reclamações e gritos de ordem contra as Organizações Globo (consideradas o maior conglomerado de empresas do setor de mídia do Brasil) por ter apoiado o Golpe Militar de 1964, que levou os militares a permanecerem no poder político durante 21 anos da história brasileira.

Motivado/interpelado a explicar a questão, o jornal $O$ Globo, pertencente às Organizações, publica, no dia 31/08/2013, editorial intitulado "Apoio editorial ao golpe de 64 foi um erro", onde explica, a partir de argumentos históricos, os motivos do apoio ao golpe, assim como reafirma o compromisso com o bom jornalismo na sociedade brasileira. Das respostas que esse enunciado suscita, analisamos duas notícias publicadas entre 31/08/2013 e 04/09/2013, para demonstrar em que medida revelam a posição axiológica de apoio ou refutação ao conteúdo do editorial em questão.

O editorial de $O$ Globo recupera a voz do jornal e de Roberto Marinho em tempo da ditadura como forma de tentar legitimar o apoio ao Regime e usar disso para se desculpar pelo que chama de equívoco. A recorrência à história é o recurso potente de sustentação dos argumentos e se configura, em várias passagens, como a estratégia escolhida para conceder voz ao próprio tempo, a fim de que se encarregue de mostrar que esse apoio era necessário.

A primeira notícia que mantém uma relação dialógica direta de resposta a esse editorial foi publicada no mesmo dia 31/08/2013, na Folha de São Paulo, em versão eletrônica (Folha UOL). A segunda é uma notícia intitulada "Clube Militar critica editorial 'mea culpa' de O Globo", publicada na revista Carta Capital em meio eletrônico, no dia 04/09/2013.

A análise das duas notícias é necessária à compreensão de como apresentam deveras uma parcialidade quase explícita a partir de visadas dialógico-valorativas de avaliação, validação, especificação e retomada de assunto.

\subsection{NOTÍCIA 1 - JORNAL 'O GLOBO’ RECONHECE QUE APOIO EDITORIAL A GOLPE DE 64 FOI 'UM ERRO'}

A notícia “Jornal 'O Globo' reconhece que apoio editorial a golpe de 64 foi 'um erro”, foi publicada pela Folha Uol no dia 31 de agosto de 2013, às 22h17, mesmo dia em que $O$ Globo publica o editorial reconhecendo o apoio ao golpe militar de 64 e defendendo o ato como um equívoco, pela manhã.

A notícia recupera, já no título, de forma indireta, o discurso de $O$ Globo, a partir da oração subordinada substantiva objetiva direta: "apoio editorial a golpe de 64 foi' 'um erro". A forma verbal delocutiva "reconhece", na oração principal, reforça o discurso de $O$ Globo e avalia positivamente o conteúdo que será lançado, numa posição de adesão - visada dialógico-valorativa de avaliação. No título, aparecem marcados com aspas "O Globo" e "um erro" a fim de retomar o discurso de $O$ Globo e também de evidenciar o objeto 
do discurso. Ao evidenciar, o autor institucional imprime sua avaliação aos objetos, nesse caso, positiva. Novamente, temos uma visada dialógico-valorativa de avaliação, agora presente na própria organização do relato, pois a demarcação dos termos com aspas tanto evidencia que pertencem a outro discurso quanto destaca os mesmos elementos.

O segundo parágrafo do texto corresponde ao lide. Repete-se o conteúdo do título (objeto do discurso) e informa-se local e data da publicação do texto, a partir dos adjuntos adverbiais de tempo e lugar, efetivando-se a disposição tempo-espacial e a identificação de participantes.

O terceiro parágrafo do texto é dedicado quase que integralmente também à recuperação do discurso de $O$ Globo, mas agora pela citação direta marcada por aspas, cujos conteúdos dos trechos colocam em evidência: a) a expressão "À luz da história" - adjunto adverbial de modo de grande importância no editorial, porque aponta para a fundamentação histórica arrolada em seu desenvolvimento; b) novamente, o objeto do discurso - o ato de reconhecimento do erro; c) argumentos complementares dispostos por $O$ Globo já no desenvolvimento do editorial, daí a necessidade de se utilizarem colchetes cercando reticências para marcar que se omitia parte do discurso lá veiculado, conforme se pode observar no excerto: "não há por que não reconhecer, hoje, explicitamente, que o apoio foi um erro […] A democracia é um valor absoluto. E, quando em risco, ela só pode ser salva por si mesma" (JORNAL..., 2013). Com essa manobra, o autor institucional coloca em evidência o conteúdo da introdução e da conclusão do editorial de $O$ Globo, cujos colchetes cercando as reticências servem à omissão da longa sustentação argumentativa baseada em fatos históricos.

Ao iniciar o terceiro parágrafo, o autor institucional se utiliza da expressão "Segundo o comunicado", referindo-se ao editorial numa relação conformativa. Posteriormente, lança novamente conteúdo recuperando a voz de $O$ Globo, numa posição de validação daquele discurso.

No quarto e último parágrafo do curto texto, que quase se assemelha a uma nota, coloca-se em evidência e reforça-se o motivo defendido por $O$ Globo para o reconhecimento do apoio ao golpe: o lançamento do sítio Memória, que conta a história do jornal, confirmando mais uma vez a informação que $O$ Globo já anunciara na introdução do editorial: o motivo de publicação do editorial não seria o clamor das ruas, mas o lançamento do sítio memória. Logo em seguida, o autor institucional, novamente, a partir de uma subordinada substantiva objetiva direta, recupera o discurso de $O$ Globo, desta vez, também o marcando com aspas. A segunda marca da recuperação do discurso de $O$ Globo para o mesmo conteúdo não seria necessária, sendo possível ler que a subordinada não funciona apenas como uma indicação dessa recuperação, mas como recurso que o evidencia. Dessa forma, observamos o efeito de validação do outro discurso, como também o de avaliação positiva.

A partir da leitura do texto, percebemos a prevalência das visadas dialógico-valorativas de avaliação e validação quando da citação do outro discurso, o que desmascara o caráter de imparcialidade da notícia, que serve à recuperação e ao reforço positivo do discurso de $O$ Globo.

\subsection{NOTÍCIA 2 - CLUBE MILITAR CRITICA EDITORIAL “MEA CULPA” DE O GLOBO}

A segunda notícia desta análise emerge de Carta Capital, num blog vinculado à revista (Blog do Lino). "Clube Militar critica editorial 'mea culpa' de O Globo" foi publicada no dia 04/09/2013, dois dias antes de Carta Capital publicar um editorial intitulado "A Ingratidão da Globo", cujo objetivo é refutar fortemente os argumentos apresentados no editorial global. A notícia revelará a coerência enunciativa de Carta Capital, socialmente reconhecida por apoiar as políticas ditas de esquerda no país.

"Clube Militar critica editorial 'mea culpa' de O Globo", como o próprio título anuncia, relata a reação de indignação do Clube Militar ao editorial publicado por $O$ Globo. A expressão latina "mea culpa", cuja origem está na prece tradicional da missa católica, a partir da qual o fiel cristão reconhece seus erros perante Deus, ironiza a forma como $O$ Globo assume o erro.

Logo abaixo do título, aparece o subtítulo, cujo conteúdo marcado por aspas representa o forte discurso do Clube Militar: "Declarar agora que se tratou de um 'equívoco' é mentira deslavada', diz entidade que reúne oficiais da ativa e ex-militares e promove comemorações da 'revolução' todo 31 de março" (BOCCHINI, 2013). 
$\mathrm{O}$ autor institucional primeiramente lança o discurso do Clube para depois especificar a quem pertence. Faz isso a partir de uma oração subordinada adjetiva restritiva que especifica/explica o que constitui a entidade. Depois soma outra oração para explicar que o Clube promove comemorações da revolução todo 31 de março. O autor avalia a posição do Clube ao destacar o termo "revolução" com aspas. Faz isso para questionar o valor com que é tomado, pois revolução tem significado positivo à luz da história, visto que se dá sempre a serviço de reparar um erro ou uma injustiça. Já "golpe" não carregaria a mesma valoração.

No primeiro parágrafo da notícia, o autor institucional delineia o lide e começa por apresentar os participantes do discurso, explicando mais uma vez o que vem a ser o Clube Militar a partir do aposto: "entidade que reúne oficiais da ativa da marinha, do exército e da polícia (e também ex-militares)" (BOCCHINI, 2013). Posteriormente, informa a data em que o Clube publica uma nota em repúdio ao editorial de $O$ Globo.

O jornal recupera o título dessa nota (Nossa opinião - Equívoco, uma ova!) e o destaca com aspas. Escolhe a forma verbal "condenando", completada por "editorial", para se referir ao objetivo da nota. Recupera novamente o título do editorial de $O$ Globo e o explica por meio de uma oração subordinada adjetiva explicativa, cujo objetivo é informar quem publicou o editorial e em que data. Posteriormente, ao se referir ao texto do editorial, o autor institucional utiliza a expressão: "O texto do veículo da família Marinho afirmava que" [e, logo em seguida, marcando com aspas, recupera a confissão]: "as Organizações Globo reconhecem que, à luz da história, esse apoio [ao golpe militar] foi um erro" (BOCCHINI, 2013). O autor usa colchetes explicativos para enfatizar o apoio ao golpe, inserindo esse termo no outro discurso. Da mesma forma, para se referir ao editorial de $O$ Globo, utiliza a expressão "o veículo da família Marinho", a partir da qual percebemos a valoração negativa, que se efetiva na visada dialógico-valorativa de retomada de assunto.

Esse primeiro parágrafo apresenta, a partir dos movimentos discursivizados a serviço estilísticocomposicional, a visada dialógico-valorativa de avaliação e a visada dialógico-valorativa de retomada do assunto, inicialmente presentes no lide. O discurso citado do Clube Militar, enquadrado no discurso novo, funciona como contrapalavra ao discurso citado de $O$ Globo.

No segundo e no terceiro parágrafos, a notícia trata de expor quase que apenas e integralmente, por meio do discurso direto marcado com aspeamento, a voz do Clube Militar. O autor institucional se vale do discurso do Clube, abundantemente, para descontruir os argumentos de $O$ Globo, numa posição de adesão ao primeiro e de refutação ao segundo.

Nos dois parágrafos que antecedem a introdução do discurso do Clube Militar, o autor institucional o anuncia, a partir de expressões avaliativas que ao mesmo tempo o validam: a) "O Clube Militar reagiu com firmeza" (BOCCHINI, 2013) - terceiro parágrafo - e, logo depois, cita o discurso do Clube: "o apoio ao Movimento de 64 ocorreu antes, durante e por muito tempo depois da deposição de Jango" (BOCCHINI, 2013); b) "E foi além" (BOCCHINI, 2013) - início do terceiro parágrafo, posteriormente lançando o discurso citado, repetindo a estratégia do parágrafo anterior: "não foi, também, como fica insinuado, uma posição passageira revista depois de curto período de engano, pois dez anos depois da revolução, na edição de 31 de março de 1974, em editorial de primeira página, o jornal publica derramados elogios ao Movimento" (BOCCHINI, 2013). Marcadamente, o discurso de outrem é introduzido a partir de visadas dialógicovalorativas de avaliação positiva, o que faz a voz do Clube Militar servir à posição defendida por Carta Capital.

Avalia-se positivamente a reação do Clube a partir do adjunto adverbial de modo "com firmeza" e soma-se o conteúdo do terceiro parágrafo ao do segundo a partir do uso de "além de", que ao mesmo tempo funciona como elemento que destaca o que será anunciado, como se dissesse: o clube disse mais coisas importantes além das ditas no segundo parágrafo.

Assim é possível afirmar que Carta Capital, por meio do blog do Lino, utiliza estratégia semelhante à da Folha UOL, mas com objetivos opostos. A Folha UOL, ao anunciar a publicação do editorial de $O$ Globo, não economiza em citá-lo e avaliá-lo positivamente, numa posição de reforço e adesão. Coube a esse veículo a função de apoiar $O$ Globo, e à revista Carta Capital, a posição de refutar aquele discurso. Por isso, o discurso do Clube Militar bem serve ao fim que Carta Capital intenta, que é o de descontruir os argumentos de $O$ Globo. 


\section{CONSIDERAÇÕES FINAIS}

A partir da análise de excertos e de enunciados na íntegra, observamos o funcionamento do enquadramento do discurso do outro na notícia, bem como descrevemos as formas linguísticas mais comuns de sua realização. $\mathrm{O}$ enquadramento do discurso de outrem e suas formas específicas de concretização podem ser mais bem observados a partir também de que se consideram as relações dialógicas, que acabam por encerrar o cruzamento de discursos e a valoração dos discursos antecedentes no discurso novo. No caso da notícia, o enquadramento é muito apropriado para que a instituição mantenha a aparente posição de imparcialidade sob o artífice da prestação de bons serviços informacionais.

Da mesma forma, os movimentos discursivizados que servem à avaliação pelo autor institucional vão além do objetivo informacional e são capazes de revelar a posição axiológica da empresa jornalística. Portanto, na notícia, as funções informacional e opinativa podem concorrer nos mesmos movimentos discursivizados estilístico-composicionalmente.

A consideração de dimensões extralinguísticas e linguísticas e de aspectos da orientação interna e externa do gênero na realidade, a partir do que preconiza a Análise Dialógica de Discurso (ADD), com base nos postulados do Círculo de Bakhtin, corrobora a compreensão do discurso, evidenciando seu caráter social e ideológico, assim como a compreensão do gênero notícia como objeto semiotizado, cujas relações dialógicas que mantém com outros gêneros do mesmo campo são essencialmente valorativas.

\section{REFERÊNCIAS}

ACOSTA PEREIRA, R; RODRIGUES, R. H. Os gêneros do discurso sob a perspectiva da Análise Dialógica de Discurso do Círculo de Bakhtin. Letras, Santa Maria, v. 20, n. 40, p. 147-162, 2010. Disponível em: <http://w3.ufsm.br/revistaletras/artigos_r40/artigo_08.pdf>. Acesso em: 8 set. 2013.

ACOSTA-PEREIRA, R. A reenunciação e as visadas dialógico-valorativas no gênero jornalístico notícia: projeções e discursividade. Letra Magna, Ano 09, n.16, 2013. Disponível em: <http://www.letramagna.com/art_16_12.pdf>. Acesso em: 10 set. 2013.

ALVES FILHO, F. A autoria institucional nos editoriais de jornais. Alfa, São Paulo, v.1, n. 50, p. 77-89, 2006. Disponível em: <http://seer.fclar.unesp.br/alfa/article/view/1396>. Acesso em: 10 set. 2013.

BAJTIN, M.; MEDVEDEV, P. N. Los elementos de la construcción artística. In: El método formal en los estúdios literarios: introducción crítica a una poética sociológica. Versión española de Tatiana Bubnova. Madrid: Alianza, 1994. p. 207-224.

BAKHTIN, M. Problemas da poética de Dostoiérski. 4. ed. Tradução de Paulo Bezerra. São Paulo: ForenseUniversitária, 2008.

Estética da criação verbal. Tradução de P. Bezerra. São Paulo: Martins Fontes, 2003.

O problema do conteúdo, do material e da forma na criação literária. In: Questões de literatura e de estética: a teoria do romance. Tradução de Aurora Fornoni Bernardini et al. São Paulo: Ed. da UNESP, 1988. p.13-70.

BAKHTIN, M. (VOLOSHÍNOV). Marxismo e filosofia da linguagem. Trad. Michel Lahud e Yara F. Vieira. 12 ed. São Paulo: Hucitec, 2006 [1929].

BOCCHINI, L. Clube Militar critica editorial "mea culpa” de O Globo. Carta Capital, Edição on line, 06 de ago. 2013. Disponível em: < http://www.cartacapital.com.br/blogs/blog-do-lino/clube-militar-criticaeditorial-201cmea-culpa201d-de-o-globo-1717.html >. Acesso em: 10 set. 2013.

BRAIT, B. Análise e teoria do discurso. In: BRAIT, B. (Org.). Bakhtin: outros conceitos-chave. São Paulo: Contexto, 2006. p. 9-33. 
; PISTORI, M.H.C. A produtividade do conceito de gênero em Bakhtin e o Círculo. Alfa, v. 56, n.2, p. 371-401, 2012. Disponível em: <http://seer.fclar.unesp.br/alfa/article/view/5531>. Acesso em: 3 jun. 2013.

CONFLITO entre 300 deixa um morto a tiro. Folha de S. Paulo, Edição on line, 26 de mar. 2012. Disponível em: <http://www1.folha.uol.com.br/fsp/esporte/33564-conflito-entre-300-deixa-um-mortoa-tiro.shtmlol.com.br/fsp/esporte/>. Acesso em: 30 mar. 2012.

DE PAUlA, L. Círculo de Bakhtin: uma Análise Dialógica de Discurso. Rev. Est. Ling., Belo Horizonte, v. 21, n. 1, p. 239-258, 2013. Disponível em: <http://www.relin.letras.ufmg.br/revista/upload/2118DEPAULA.pdf>. Acesso em: 02 fev. 2014.

FARACO, Carlos Alberto. Autor e autoria. In: BRAIT, Beth (Org.). Bakhtin: conceitos-chave. 4. ed. São Paulo: Contexto, 2007. p. 37-60.

FERNANDES, S. D. S. Brasil tem rombo recorde nas contas externas. Folha de S. Paulo, Edição on line, 25 de jan. 2014. Disponível em: <http://www1.folha.uol.com.br/fsp/mercado/149221-brasil-tem-romborecorde-nas-contas-externas.shtml>. Acesso em: 28 jan. 2014.

GAVAZZI, S.; RODRIGUES, T.M. Verbos dicendi na mídia impressa: categorização e papel social. In: PAULIUKONIS, M.A.L.; GAVAZZI, S. Texto e discurso: mídia, literatura e ensino. Rio de Janeiro: Lucerna, 2003. p.51-61.

GRILLO, S. V. de C. A produção do real em gêneros do jornal impresso. São Paulo: Humanitas, 2004.

Polifonia e transmissão do discurso alheio no gênero reportagem. Estudos Linguísticos XXXIV, Campinas, v. 1. p. 1164-1169, 2005. Disponível em <www.fflch.usp.br/dlcv/lport/pdf/shgro11.pdf>. Acesso em: 25 jul. 2008.

JORNAL 'O Globo' reconhece que apoio editorial a golpe de 64 foi 'um erro'. Folha de S. Paulo, Edição on line, 01 de ago. 2013. Disponível em: <http://www 1.folha.uol.com.br/poder/2013/08/1335274-jornal-oglobo-reconhece-que-apoio-editorial-a-golpe-de-64-foi-um-erro.shtm>. Acesso em: 10 de set. 2013.

JUBANSKI, E.; HERNIQUE, B. Garota é brutalmente assassinada e “colegas" preferem silêncio sobre possível autor. Banda B., 15 de jan. 2014. Disponível em: <http://www.bandab.com.br/jornalismo/garotabrutalmente-assassinada-colegas-preferem-silencio-possivel-autor/>. Acesso em: 18 jan. 2014.

KOCH, I.V. Referenciação e orientação argumentativa. In: (Org.). Referenciação e discurso. São Paulo: Contexto, 2005. p. 33-52. ; MORATO, E. M.; BENTES, A. C.

MELO, J. Casa Civil advertiu sobre cláusulas lesivas na compra da refinaria de Pasadena. NE10. Recife, o3 de mar. 2014. Disponível em: http://blogs.ne10.uol.com.br/jamildo/2014/03/22/Casa-Civil-advertiusobre-cláusulas-lesivas-na-compra-da-refinaria-de-Pasadena/. Acesso em: 03 mar. 2014.

PIMENTEL, C. Governo envia ao Congresso proposta de lei que criminaliza exigência de cheque caução em hospitais privados. Agência Brasil, 06 de mar. 2012. Disponível em: <http://memoria.ebc.com.br/agenciabrasil/noticia/2012-03-06/governo-envia-ao-congresso-proposta-delei-que-criminaliza-exigencia-de-cheque-caucao-em-hospitais-pr>. Acesso em: 08 mar. 2012.

RABAÇA, C. A. ; BARBOSA, G. Dicionário de Comunicação. 3.ed. São Paulo: Ática, 1998.

ROJO, R. Gêneros do Discurso e Gêneros Textuais: Questões Teóricas e Aplicadas. In: MEURER, J.L.; BONINI, A.; MOTTA-ROTH, D. (Org.). Gêneros: teorias, métodos e debates. São Paulo: Parábola Editorial. 2005. p. 184-207. 
Gêneros do discurso no círculo de Bakhtin: ferramentas para a análise transdisciplinar de enunciados em dispositivos e práticas didáticas. In: SIMPÓSIO INTERNACIONAL DE ESTUDOS DE GÊNEROS TEXTUAIS (SIGET), 4., Tubarão, SC. Anais... Tubarão: UNISUL, 2007. p. 1761-1775.

SAIZ, E. Obama afirma que o referendo da Crimeia viola a lei internacional. El Pais, Edição Brasil on line, 06 de mar. 2014. Disponível em: <http://brasil.elpais.com/brasil/2014/03/06/internacional/1394114869_100567.html>. Acesso em: 08 mar. 2014.

SIGNORINI, I. Do residual ao múltiplo e ao complexo: o objeto da pesquisa em Linguística Aplicada. In: SIGNORINI, I.; CAVALCANTI, M. Linguística Aplicada e Transdisciplinaridade. Campinas: Mercado de Letras, 1998. p. 99-110.

WELLE, D. Dilma rebate críticas a emergentes e "vende" Brasil a investidores em Davos. Carta Capital, Edição on line, 24 de jan. 2014. Disponível em:

$<$ http://www.cartacapital.com.br/politica/dilma-rebate-criticas-a-emergentes-e-vende-brasil-ainvestidores-em-davos-2301.html>. Acesso em: 05 out. 2013.

Recebido em 25/06/2014. Aprovado em 24/05/15. 